\author{
Ewa Szatan
}

Uniwersytet Gdański

\title{
TWÓRCZOŚĆ I KREATYWNOŚĆ DZIECI NA ZAJĘCIACH MUZYCZNO-RUCHOWYCH (Z DOŚWIADCZEŃ W PRACY W ŚRODOWISKU MAŁOMIEJSKIM)
}

\begin{abstract}
Abstrakt: Współczesność stawia przed człowiekiem różne wyzwania, z których wiele wiąże się z potrzebą bycia twórczym. Amatorska aktywność muzyczna, edukacja czy kształcenie muzyczne sprzyjają twórczości, jednakże w edukacji dzieci młodszych ten obszar jest zaniedbany, a kreatywność to często tylko puste hasło w podstawie programowej. W artykule opisano projekt muzyczny zrealizowany w ramach zajęć pozaszkolnych. Uczestniczyły w nim dzieci mieszkające na terenach wiejskich. Miał u swych podstaw założenia rytmiki Dalcroze’a, a jedną z przyjętych strategii było działanie muzyczne nastawione na samodzielność dzieci i stymulację zachowań twórczych. Projekt pokazał, jak bardzo można rozwijać dziecko i uwolnić jego emocje, pozwalając mu na bycie twórczym. Przeżywanie muzyki i sytuacje z tym związane sprzyjają rozwojowi poznawczemu, emocjonalnemu, estetycznemu i społecznemu, zatem zarówno nauczyciele, jak i rodzice powinni świadomie stosować strategie stymulowania muzycznej twórczości dzieci i pobudzania ich kreatywności. Nauczyciel czy instruktor może wykorzystać w tym celu interpretacje ruchowe tak często lekceważonej i niedocenianej, bo nieznanej muzyki poważnej.
\end{abstract}

Słowa kluczowe: dziecko, kreatywność, muzyka, interpretacje ruchowe muzyki

\section{WPROWADZENIE}

Wśród wielu wyzwań, jakie stawia przed człowiekiem XXI wiek, pojawiają się modne hasła bycia kreatywnym i twórczym, wykazywania się twórczą postawą oraz podejmowania innowacyjnych działań, pożądane i mile widziane zwłaszcza przez 
pracodawców. Obywatel w swoim miejscu pracy ma być nie rzemieślnikiem, lecz artystą - kimś o dużym potencjale, aktywnym, nieszablonowym i pomysłowym. Współczesne społeczeństwa potrzebują takich obywateli i już na etapie edukacji stawiają na wykształcenie określonych cech u dzieci. Twórczość i kreatywność są zatem obecne w podstawie programowej wychowania przedszkolnego i w edukacji szkolnej (Rozporządzenie Ministra... 2016). Szeroko rozumiana edukacja muzyczna, specjalistyczne kształcenie muzyczne czy muzyka w ruchu amatorskim stają się formami aktywności muzyka-nauczyciela, czynnego artysty oraz animatora, którzy potrafią szybko podążać za modą i promować kreatywność w swojej pracy, a także stymulować ją u dzieci. Pojawia się jednak pytanie: „Czy dzieci, które nie uczestniczą w procesie specjalistycznego kształcenia muzycznego, mają szansę na rozwój wymienionych cech?”. Różne działania z założenia zapewniają im pełny dostęp do nauki i wyrównują różnice w kształceniu i wychowaniu występujące między środowiskiem miejskim a wiejskim, czyli także przyczyniają się do niwelowania różnic w dostępie do zajęć rozwijających twórczość i kreatywność (Rozporządzenie Ministra... 2016). Dynamizm zmian nie kryje się tylko w podręcznikach, a głównie w sposobie realizacji treści programowych. I nawet ulegające zmianom standardy kształcenia studentów pedagogiki wczesnoszkolnej, które mogłyby powodować wzrost kreatywności wśród studentów, czyli przyszłych nauczycieli, a następnie u ich uczniów, tego nie czynią ${ }^{1}$ Zaniedbuje się obszar związany z edukacją artystyczną dzieci, co szczególnie uderzające jest w klasach młodszych pierwszego etapu kształcenia (Szatan 2006; Weiner 2000; Weiner 2002). Wychowawca bez wykształcenia muzycznego czy plastycznego pomija wiele dziedzin sztuki, które rozwijają twórczość i kreatywność dziecka. Dostrzega się brak zrozumienia dla wagi sztuki we wczesnej edukacji także ze strony rodziców. W przedszkolu zajęcia muzyczne nie zawsze odnoszą się do założeń rytmiki Emila Jaques-Dalcroze’a czy metody Carla Orffa. Czasami są to zajęcia, na których dzieci tylko śpiewają piosenki i przygotowują program artystyczny na różne uroczystości, a brakuje systematycznej pracy nad rozwojem muzycznym, co odbija się na jakości dziecięcych występów. Zamiast rozwijania zdolności muzycznych i wrażliwości dziecka oraz wzbudzania jego postaw twórczych zauważa się działania krótkofalowe, podejmowane na zasadzie akcyjności, od jednego występu do następnego. W dalszej edukacji, w szkole podstawowej, nie ma warunków do prowadzenia zajęć muzyczno-ruchowych (brak nauczyciela-specjalisty w zakresie rytmiki, instrumentu, czyli pianina, oraz przestrzeni do ćwiczeń). W podstawie programowej zaś są obecne już tylko szczątki haseł związanych z zajęciami rytmicznymi i pozostałymi formami aktywności

1 W literaturze polskiej krytyczne stanowisko zajmuje w tej problematyce m.in. Dorota Klus-Stańska. Można zauważyć, że samo studiowanie nie spowoduje zmian w podejściu nauczyciela do edukacji dziecka i jego działań twórczych, potrzeba tutaj zmian w obszarze mentalności nauczyciela. 
muzycznej. Nie ma sprzyjającej atmosfery dla twórczości dziecięcej, pozostaje miernej jakości odtwórczość. Dzieci z obszarów małomiejskich i wiejskich nie uczestniczą w zajęciach rozwijających kreatywność i twórczość muzyczną (np. rytmicznych), gdyż nie mają do nich dostępu. Stan ten wywołuje potrzebę muzycznego aktywizowania dzieci poza zajęciami szkolnymi. Odrębnym problemem jest ograniczony dostęp społeczności lokalnych do kultury wyższej (zob. Szatan 2016).

\section{KREATYWNOŚĆ I TWÓRCZOŚĆ W MUZYCZNEJ EDUKACJI WCZESNOSZKOLNEJ}

Stawiając pytanie o twórczość, już od dawna znajdujemy na nie różne odpowiedzi. Wielu autorów przyczyniło się do debaty nad próbą zdefiniowania nie tylko samej twórczości, ale także innych terminów z nią kojarzonych, np. postawa twórcza czy twórcze działanie (Bruner 1978; Trzebiński 1978; Rogers 2012). W ostatnich latach polscy badacze zabierają głos w dyskusji na temat twórczości. Jest wśród nich Edward Nęcka, który dostrzega wieloznaczność tego pojęcia i wskazuje, że samo zjawisko twórczości „stanowi ważny i ciekawy przedmiot badań naukowych” (Nęcka 2001, s. 12). Inny badacz, Krzysztof Schmidt, opisuje twórczość jako pewną działalność, która przynosi wytwory w postaci dzieł sztuki czy wynalazków, jak również określonych metod działania. W rozumieniu Schmidta wytwory powinny mieć np. wartość poznawczą, estetyczną czy etyczną i stanowić nowość przynajmniej dla samego podmiotu tworzącego (Schmidt 2005).

Twórczością jest działalność, ale także twórczość określana jest jako cecha człowieka, który podejmuje różne działania i część z nich ma charakter twórczych przedsięwzięć ${ }^{2}$. Krzysztof Schmidt mówi, że z twórczością utożsamiana jest kreatywność, czyli „zdolność człowieka do w miarę częstego generowania nowych i wartościowych wytworów (rzeczy, idei, metod działania itd.)" (Schmidt 2005, s. 53).

Niniejszy tekst porusza problem twórczości w rozumieniu pedagogiki i muzycznej aktywności dziecka, stąd należy wskazać, że jeżeli ma ona mieć taki właśnie pedagogiczny sens, to badacz kreatywnością nazywać powinien „zachowania i cechy człowieka (ucznia, studenta, pracownika itd.)" (Schmidt 2005, s. 53). Nęcka termin twórczość rezerwuje dla cech wytworu i całego dorobku twórcy, a w odniesieniu do osoby używa pojęcia kreatywności (Nęcka 2001). W moich rozważaniach są to ważne definicje, gdyż opisuję zajęcia muzyczno-ruchowe i przywołanie twórczości choreograficznej, np. Alvina Aileya czy Maurice Bejarta, wskazuje na ich

2 W literaturze światowej, np. u Yingxu Wanga (2009), na pytanie: „What is the nature of creativity?" znajdziemy odpowiedź: "Creativity is the intellectual ability to make creations, inventions, and discoveries that brings novel relations, entities, and/or unexpected solutions into existence". 
paralelność - nie można odmówić im ani rozwijania działań twórczych w samej warstwie muzyczno-tanecznej choreografii, ani pobudzania kreatywności przy przygotowywaniu spektakli baletowych (np. scenografii, kostiumów, oświetlenia). Nęcka wskazuje, że „kreatywność przejawia się zwykle w jakiejś formie obserwowalnego zachowania, polegającego na produkcji nowych i wartościowych wytworów [...], przy czym niekiedy wytworem może być już samo zachowanie (np. w wypadku twórczości choreograficznej)” (Nęcka 2001, s. 19). „Podobnie można by spostrzegać kreatywne działania związane z przygotowywaniem interpretacji ruchowych na koncert rytmiki i jej poszczególne etapy (interpretacje muzyki ruchem w rozumieniu rytmiki Dalcroze’a), ze szczególnym uwzględnieniem improwizacji ruchowej jako twórczości ruchowej” (Szatan 2016).

Twórczość wpisana jest w różne obszary ludzkiej aktywności. W rozwoju twórczej postawy dziecka znaczącą rolę odgrywają bliskie jemu środowiska: dom rodzinny, przedszkole czy szkoła. Różnorodne formy zajęć pozaszkolnych, których głównym celem jest umuzykalnienie (np. zajęcia muzyczno-ruchowe), rozwijają ten rodzaj aktywności. Dziecko, które z natury jest ciekawe i potrafi wyrażać zdziwienie, wpisuje się w definicję twórczego przedsięwzięcia Jerome’a S. Brunnera, ważną dla moich dalszych rozważań. „Znakiem rozpoznawczym twórczego przedsięwzięcia będzie dla mnie takie działanie, którego wynikiem jest skuteczne zdziwienie. Treść zdziwienia może być tak rozmaita, jak rozmaite są ludzkie przedsięwzięcia" (Bruner 1978, s. 362). W aktywności muzyczno-ruchowej dziecko działa w taki sposób, aby zadziwić zarówno samego siebie, jak i otoczenie.

\section{SPOSTRZEŻENIA Z ZAJĘĆ TWÓRCZYCH W ŚWIETLE BADAŃ WŁASNYCH ${ }^{3}$}

Dzieci w środowiskach poza dużymi miastami mają ograniczone możliwości wyboru spędzania wolnego czasu w kontakcie z muzyką artystyczną. Jedną z ofert może być nauka w szkole muzycznej, o ile taka w danej miejscowości istnieje, czy np. uczestnictwo w zespole pieśni i tańca, czasami w chórze. Istotą tych zajęć (poza wyjątkami w szkole muzycznej) jest odtwarzanie muzyki. Ich oferta w obszarach małomiejskich i wiejskich ma szczególne znaczenie, gdy stają się nie tylko rodzajem określonej aktywności, lecz mogą także, jak w opisanym przeze mnie przypadku, przybliżać kulturę muzyczną i rozbudzać w dzieciach potrzebę kontaktu z muzyką artystyczną oraz uwalniać emocje czy rozwijać postawy twórcze i kreatywne.

${ }^{3}$ Dokładniej swoje badania opisałam w artykule Idea wykorzystania pracy zespołowej $w$ doświadczaniu muzyki. Zajęcia muzyczno-ruchowe jako pole dla twórczości i kreatywności dzieci (Szatan 2016). 
Dlatego przez dwa lata realizowałam projekt - twórcze zajęcia muzyczno-ruchowe w Centrum Inicjatyw Edukacyjnych (CIE) w Kartuzach oparte na rytmice Dalcroze'a ${ }^{4}$. Stworzyły one dzieciom możliwość rozwoju nie tylko muzykalności, lecz także postaw twórczych i kreatywności. Na zakończenie zajęć odbył się występ uczestników przed publicznością na koncercie rytmiki w środowisku zupełnie dla nich obcym - dużej szkole muzycznej w Gdańsku. Na cotygodniowe spotkania uczęszczało sześć dziewcząt $\mathrm{w}$ wieku od pięciu i pół do czternastu lat ${ }^{5} \mathrm{i}$ jeden czteroipółletni chłopiec. Grupa ze względu na dużą rozpiętość wieku uczestników była dość nietypowa i można powiedzieć, że już podczas jej tworzenia doszło do "przekraczania granic" i łamania schematów, czyli tego, co odnosimy do procesu tworzenia i kreacji.

W interpretacji muzyczno-ruchowej środkami wyrazu są ruchy ciała w przestrzeni i gesty. Czasami wykorzystuje się także różne pomoce - rekwizyty wzbogacające przekaz i wzmacniające siłę ekspresji. To one inspirowały dzieci podczas zajęć do poszukiwań rozwiązań ruchowych odpowiadających wyrazowi muzyki, decydowały o ich ostatecznym kształcie (np. dzieci wybierały ze wskazanych rekwizytów te, które ich zdaniem bardziej podkreślały muzykę; wskazywały kolory pasujące do charakteru muzyki, ale także uczyły się kompromisu, gdy barwa rekwizytu nie odpowiadała nastrojowi w muzyce i należało wybrać inny), były narzędziami do prezentowania kreatywności. Wszystkie „wytwory”, jak zauważyłam, stawały się dla dzieci źródłem przyjemności (wynik swojej pracy oglądały na video) i dumy, że ich pomysły były wykorzystane w interpretacji ruchowej utworów. Obserwacja uczestników zajęć muzyczno-ruchowych pozwoliła mi na spostrzeżenie, że ożywiały się one, gdy pojawiał się problem do rozwiązania, albo gdy same wymyślały sobie zadania do wykonania. Pozwalałam dzieciom na eksperymentowanie, co doprowadziło mnie do sformułowania wniosków, że twórczość:

- uprzyjemniała dzieciom zajęcia (nie nudziły się);

4 „Zajęcia muzyczne, rytmika, pozwalają na zaspokojenie naturalnej potrzeby dziecka - potrzeby ruchu. Wykonywane przez dzieci ćwiczenia, które stymuluje muzyka dają im możliwość pełnego zaangażowania w działanie. Pomysły dzieci, przyczynek do ich twórczości, generują tutaj problemy muzyczne występujące w słuchanej muzyce. Proces tworzenia interpretacji ruchowych do muzyki, następnie doskonalenie jego wykonania w przestrzeni, przygotowanie do występu na koncercie i sam moment kluczowy - występ, stają się okazją by dzieci na każdym etapie wykazywały się muzykalnością, samodzielnością myślenia, zdolnością do pokonywania trudności, twórczością muzyczno-ruchową, ale także odwagą w podejmowania działań, które nazwę kreatywnymi. Skład grupy tak bardzo zróżnicowanej wiekowo spowodował, że tworzenie interpretacji ruchowej do muzyki wymagało przemyślenia i dostosowania do możliwości wykonawców - bardzo dziecięcej ekspresji i naturalnego ruchu trójki najmłodszych dzieci połączonej z dużymi możliwościami technicznymi i wyrazowymi najstarszych dziewczynek." (Szatan 2016)

5 W drugim roku odeszła najstarsza, czternastoletnia uczestniczka zajęć - ich kontynuowanie uniemożliwiły jej obowiązki w szkole średniej. 
- odprężała, inaczej niż zadania odtwórcze, które dzieci traktowały bardziej poważnie, jako coś do zapamiętania, bo trzeba się „nauczyć, by za każdym razem wykonywać tak samo" (tak jak w szkole);

- wzbudzała dość często silne emocje i motywacje do dalszej pracy; zadania twórcze naturalnie samodyscyplinowały, a odtwórcze wiązały się z odpowiedzialnością za wspólny wysiłek i przygotowanie się do koncertu.

\section{PRZEJAWY POSTAW TWÓRCZYCH I KREATYWNOŚCI DZIECI W PROJEKCIE}

Podczas zajęć obserwowałam najmłodszych w działaniu. Ich aktywność potwierdziła moją tezę, że dzieci są twórcze w określonych, sprzyjających twórczości sytuacjach oraz położeniach. W tym przypadku były to „zaczarowane miejsce” CIE i atmosfera wyzwalająca twórczość. Niewielkich rozmiarów sala do ćwiczeń miała bardzo kameralny charakter (odbywały się w niej także zajęcia plastyczne i różne dekoracje pozostawały tam przez dłuższy czas). Klimat twórczej pracy wyczuwało się już po wejściu do środka. Dzieci wiedziały, że są tutaj kimś ważnym. Różne sprzęty i dekoracje w tej sali, tworzone przez rówieśników na zajęciach plastycznych czy teatralnych, miały dla mojej grupy zajęciowej znaczenie, sprzyjały improwizacji. Czasami były „kamieniami, za którymi można się schować” (np. manekin stojący pod ścianą, uchylone drzwi na korytarz) lub „jaskinią" (tak określił miejsce pod stołem najmłodszy uczestnik zajęć). Krążki-poduszki do siadania na podłodze ułożone zostały przez dzieci w wysoki stos i stały się „wieżą króla gór” w improwizacji ruchowej do muzyki Edwarda Griega Peer Gynt (W grocie króla gór); innym razem tworzyły kształt kwiatu - jeden krążek był jednym płatkiem.

Klimat sprzyjający twórczości powstał dzięki ludziom - dyrektorce CIE i personelowi - zawsze życzliwym i służącym pomocą, podejmującym rozmowy z dziećmi, które przychodziły do CIE. Ważnymi postaciami byli sami rodzice dzieci, z którymi nawiązałam kontakt i omawialiśmy różne sprawy związane z zajęciami i koncertem. Prowadząc zajęcia, starałam się o stworzenie atmosfery, w której to dzieci organizowały pracę, czuły się za nią odpowiedzialne i wykazywały samodyscyplinę, co nie zawsze było łatwe i wymagało czasu. Uczestnicy zajęć wzajemnie inspirowali się i zachęcali do działania, nie bali się zadawać pytań. Wiele zachowań dzieci okazało się nowymi doświadczeniami społecznymi, gdy określony wytwór ruchowy jednego zyskiwał aprobatę pozostałych, a czasami podziw, kiedy okazał się potrzebny w realizacji zadania należącego do całej grupy. Na przykład najmłodsza dziewczynka pod wpływem ćwiczeń w grupie przygotowała sobie w domu kompozycję taneczną (zastosowała nazwę, którą słyszała 
na zajęciach) z wykorzystaniem rekwizytu - krótkiej wstążki. Podczas prezentacji poruszała się w ciszy (muzykę słyszała wewnątrz siebie). Po pewnym czasie zaczęła improwizować ruchem melodię, nadal rytmicznie poruszając wstążką. Można było zauważyć, z jaką starannością i precyzją ćwiczyła w domu prezentację. Jej taniec pobudził do twórczości chłopca, który zaangażował się w pokaz i zaczął swobodnie wystukiwać rytm do jej ruchów. To zaś zainspirowało kolejną dziewczynkę do wystukiwania o podłogę „pulsu muzycznego”. Działanie jednego z dzieci wywołało więc interakcję pozostałych. Okazało się to doświadczeniem ciekawym, niepowtarzalnym, niezwykłym i zaskakującym dla samych uczestników zajęć ${ }^{6}$. Dzieci były radosne, chciały zaimprowizować jeszcze raz i stworzyć następny taniec. Nagrodziły występ dziewczynki oklaskami. Podkreśliły, że w szkole czy przedszkolu tak spontanicznie nigdy nie występowały. Ważna dla nich była możliwość pokazania innym swojego pomysłu i stworzenie grupy wykonawców, w której każdy miał swoje zadanie ${ }^{7}$.

\section{MUZYCZNY PROJEKT A FUNKCJE AKTYWNOŚCI TWÓRCZEJ}

Aktywność twórcza dziecka spełnia określone funkcje (Schmidt 2005, s. 177). W zajęciach muzyczno-ruchowych występowały takie działania, które poddają się ocenie przy zastosowaniu kryterium oryginalności i użyteczności (Runco, Charles 1997). Można zatem wskazać aktywność twórczą oraz jej dwie funkcje: ekspresyjną i terapeutyczną. Na opisywanych zajęciach dzieci wypowiadały się o muzyce werbalnie lub ruchem. Tworzyły zasady do zadań muzycznych i proponowały ich warianty, które były włączane do interpretacji ruchowej. Z radością wymyślały ruch do muzyki, co pozwalało na odreagowanie nagromadzonych napięć i uwolnienie emocji. Dzieci bardzo siebie wspierały, a jednocześnie przyjmowały określone role w grupie. Integrowały się, gdy tworzyły wspólnie kompozycję ruchową. Uczyły się zażegnywania konfliktów, wypracowywania kompromisów, gdy decydowały, który pomysł ruchowy będzie najlepiej oddawał muzykę. Zmieniły się relacje między dziećmi - starsze stały się bardziej opiekuńcze, a młodsze obdarzyły je zaufaniem, by w trudnych sytuacjach prosić o pomoc. U chłopca ustabilizowały się emocje - obserwowałam mniej wahań nastrojów i większą pewność w działaniu. Z kolei młodsze dziewczynki były bardziej cierpliwe przy odtwarzaniu muzyki i kilkukrotnych powtórkach elementów, które należało opanować. W życiu opisywanej grupy

\footnotetext{
6 Takie działanie obserwujemy w koncepcji dziecięcego tworzenia muzyki Orffa.

7 Nasuwa się porównanie do grających muzyków jazzowych, z których każdy w zespole realizuje się indywidualnie, a jednak wszyscy improwizują na wspólny temat.
} 
dzieci zarówno aktywność twórcza, jak i ekspresja spełniały funkcję rozwojową, a zajęcia muzyczne - funkcję edukacyjną aktywności twórczej.

\section{PODSUMOWANIE}

Zajęcia muzyczno-ruchowe według koncepcji Jaques-Dalcroze’a rzadko są opisywane przez rytmików jako obszar badawczy, podjęłam więc tę tematykę, by wypełnić lukę. Zrealizowany projekt muzyczny doprowadził mnie do ciekawych spostrzeżeń. Wnioski wysunęłam na podstawie obserwacji dzieci na zajęciach, rozmów z nimi oraz z ich rodzicami. Stawiałam sobie pytania o twórczość dziecka, o jego twórczą postawę i kreatywność. Jakie znaczenie dla dziecięcej twórczości mają środowisko oraz spotkania $\mathrm{z}$ muzyką $\mathrm{w}$ kontekście możliwości wypowiadania się w muzyce?

1. Zauważyłam, że środowisko małego miasta czy wsi nie daje dzieciom takich szans rozwoju jak środowisko dużego miasta. To wskazówka dla nauczycieli, że ze szczególną troską powinni podchodzić do procesu dydaktycznego, tworzyć atmosferę pracy sprzyjającą poszukiwaniom nowych doświadczeń. Dla dziecka nauka może być przygodą, co zostało dowiedzione podczas naszej pracy na zajęciach muzyczno-ruchowych, na które uczestnicy przychodzili radośni, z oczekiwaniem, co nowego zaproponuję. Pytali o „niespodzianki”, czyli zadania twórcze przygotowywane przeze mnie, stwarzające okazje do coraz większego zaskakiwania pomysłami oraz inspirowania siebie nawzajem.

2. Znaczące dla twórczości były miejsce i osoby, które dzieci spotykały na zajęciach i przed nimi. Atmosfera pracy twórczej rodziła się od pierwszej minuty spotkania - panował wzajemny szacunek, a zasady postępowania ustalane były przez dzieci. Osoby, z którymi uczestnicy zajęć mieli kontakt, nie podnosiły głosu, nie niecierpliwiły się, dawały czas do namysłu i wykonania zadań, co okazało się dla dzieci zaskakujące. Na jednym ze spotkań zwróciły uwagę, że w ich w szkołach nauczyciele często „krzyczeli" na uczniów.

Otwartość nauczyciela na potrzeby dziecka i podążanie za nim, pozwalanie dziecku na wcielanie w życie pomysłów - to pierwszy krok, by dać szansę na bycie kreatywnym. Projekt zrealizowany z dziećmi w CIE pokazał, że w polskiej szkole (w tym przypadku w środowisku wiejskim i małomiejskim) nauczyciele mało pomagają uczniom w byciu osobami twórczymi i kreatywnymi, choć dzieci potrzebują zajęć, na których ważne są działania innowacyjne. W projekcie przewidziano dużo okazji do rozwijania twórczości, jednak był także czas na ćwiczenie i doskonalenie umiejętności ruchowych i muzycznych podczas interpretacji utworów. Wiele 
trudnych dla dzieci problemów może rozwiązywać nauczyciel - niezwykle taktowny, twórczy i kreatywny, gotowy na taką samą postawę ucznia, wykazujący się otwartością, ale także poczuciem humoru. Dzieci w CIE otwarcie mówiły, że lubią nauczyciela uśmiechniętego. Bycie bardzo poważnym może paraliżować najmłodszych, którzy nie otworzą się, nie zaryzykują bycia aktywnymi w obawie przed surową oceną nauczyciela. Moja postawa na zajęciach miała wyzwalać u dzieci chęć zabawy i pracy, jednak nie chciałam zadań mających prowadzić do uwolnienia przejawów kreatywności traktować jako rozrywki. Gdy w odczuciu dzieci pewne działania były tylko zabawą, w rzeczywistości pobudzały do intensywnego wysiłku intelektualnego, a w przypadku interpretacji ruchowej utworu muzycznego - także fizycznego. Dlatego czasami zdarzały się sytuacje, gdy należało dziecku wyjaśnić potrzebę podjęcia wysiłku na rzecz pracy zespołowej i wówczas potrafiło ono pokonać gorszą dyspozycję (np. ogólne zmęczenie po całym tygodniu pracy). Moja otwartość na różne potrzeby uczestników zajęć powodowała, że chcieli oni mi zaufać i pokonywać pewne słabości. Ich wysiłek traktowałam poważnie, gdyż proces twórczy wymagał od dzieci koncentracji, wytrwałości i determinacji, by mogły osiągnąć sukces. Moja koncepcja utworu na zajęciach była istotna dla wspólnej pracy, ale zawsze podpatrywałam dzieci i gdy pomysł któregoś z nich odpowiadał treściom muzycznym utworu, to włączałam go do realizacji, rezygnując z własnego planu. W ten sposób każde dziecko miało swój element w utworze i świadomość, że twórczość i kreatywność zawsze traktowałam poważnie.

Dzieci z grupy zajęciowej w Kartuzach uważam za wyróżniające się pomysłowością i poszukujące nowych, ciekawych rozwiązań. Kombinacja ich umiejętności, cech osobowości i doświadczeń czynią je bardziej lub mniej zdolnymi do wyrażenia swojego potencjał twórczego, ale nie jest to argument, by przejawy kreatywności dziecięcej pozostawiać na co dzień przypadkowi. Innym dzieciom w przedszkolu czy szkole bywają potrzebne zachęta i wsparcie ze strony nauczyciela. Doświadczenia z zajęć pokazały mi, że bardzo kreatywni uczniowie znajdą własne rozwiązania problemu, niezależnie od tego, co dzieje się w ich szkole, w niesprzyjającym twórczości środowisku. Dlatego tak znaczące są uzupełniające zajęcia pozaszkolne. Dzieci potrzebują stymulacji, by twórczo rozwiązywać problemy, a dorośli mogą w tym pomóc poprzez zabawę i dobrą muzykę, która wspiera, stymuluje działania, na co skrzętnie zwracałam uwagę podczas zajęć ${ }^{8}$.

Zajęcia muzyczne, ćwiczenia problemowe wymagają nietypowego podejścia. Nie zawsze trzeba mieć wiedzę i umiejętności, by być twórczym. Czasami to właśnie rozwiązanie problemu doprowadza do zdobycia nowych kompetencji. Z jednej

8 Zauważa się to w aktywności dziecięcej przy zastosowaniu metodzy Orffa czy Jaques-Dalcroze’a. 
strony ciągłe odwoływanie się do reguł i zasad, stosowanie rozległej wiedzy i doskonalenie jej, rozwój umiejętności bez stymulacji do ekspresyjnego i impulsywnego działania mogą być ogłupiające. $Z$ drugiej jednak strony wiedza i umiejętności są podstawą kreatywności. Rozeznanie w świecie to punkt wyjścia do zabawy małych dzieci. A jak ludzie (dzieci i dorośli) mogą wyrażać swoją kreatywność bez rozwijania niezbędnych umiejętności? Skąd mają wiedzieć, że ich wkład w jakieś przedsięwzięcie był oryginalny, jeżeli nie rozumieją pewnych treści? W zakresie aktywności ruchowej podstawowa technika ruchu (funkcjonalna, czyli wynikająca z możliwości anatomicznych i psychomotorycznych) jest niezbędna do zrozumienia muzyki i jej wartości. Dlatego powinno się zadbać o to, by wyrównywać szanse dzieci z małych ośrodków miejskich i wsi oraz nauczyć ich krytycznej oceny zarówno własnych wytworów, jak i wytworów innych osób (Szatan 2016).

Marzena Brzozowska-Kuczkiewicz pisze, że improwizacja ruchowa, czyli akt tworzenia, kształci świadomość ruchu wykonawców oraz „daje poczucie pewności siebie i pozwala wykonać to, co uważa się za stosowne, co czuje, na co ma ochotę" (Brzozowska-Kuczkiewicz 1991, s. 202). Dlatego nauczyciele nie powinni zapominać o tym przesłaniu i świadomie stosować strategię stymulowania muzycznej twórczości i kreatywności dzieci. Będzie to zapewne procentowało w przyszłości.

\section{LITERATURA}

Bruner J., 1978, Poza dostarczone informacje. Studia z psychologii poznawania. Tłum. B. Mrozik. Warszawa, Wydawnictwo Naukowe PWN.

Brzozowska-Kuczkiewicz M., 1991, Emil Jaques-Dalcroze i jego rytmika. Warszawa, WSiP.

Burowska Z., 1976, Współczesne systemy wychowania muzycznego. Warszawa, WSiP. Červinková H., Gołębniak B.D., 2013, Edukacyjne badania w działaniu. Warszawa, Wydawnictwo Naukowe Scholar.

Czerepaniak-Walczak M., 2010, Badanie w działaniu. W: S. Palka (red.), Podstawy metodologii badań w pedagogice. Gdańsk, GWP.

Gloton R., Clero C., 1985, Twórcza aktywność dziecka. Warszawa, WSiP.

Kujawiński J., 1990, Rozwijanie aktywności twórczej uczniów klas początkowych.

W: J. Kujawiński (red.), Rozwijanie aktywności twórczej uczniów klas początkowych. Zarys metodyki. Warszawa, WSiP.

Michalak B., 2009, Schulwerk Carla Orffa. Idea muzyki elementarnej i jej recepcja. Poznań, Wydawnictwo PTPN.

Nęcka E., 2001, Psychologia twórczości. Gdańsk, GWP. 
Runco M.A., Charles R.E., 1997, Development trends in Creative Potential and Creative Performance. W: Runco M.A. (red.), Cresskill. The Creativity Research Handbook, t. 1. Nowy Jork, Hampton Press.

Runco M.A., 2005, Reasoning and Personal Creativity, opublikowano: http://creativitytestingservices.com/satchel/pdfs/2006\%20reasoning\%20chap\%20052184 3855c05_p99-116.pdf [dostęp: 17.04.2016].

Sawyer R.K. i in., 2003, Creativity and Development. Nowy Jork, Oxford University Press.

Schmidt K., 2005, Pedagogika twórczości. Sopot, GWP.

Smolińska-Theiss B., Theiss W., 2013, Badanie i działanie w pedagogice społecznejmiędzy tradycją a współczesnymi zadaniami. W: H. Červinková, B.D. Gołębniak (red.), Edukacyjne badania $w$ działaniu. Warszawa, Wydawnictwo Naukowe Scholar.

Suświłło M. (red.), 2006, Zaniedbane i zaniechane obszary edukacji w szkole. Olsztyn, Wydawnictwo UWM.

Szatan E., 2006, Ekspresja muzyczno-ruchowa jako zaniedbany obszar edukacji muzycznej dziecka. W: M. Suświłło (red.), Zaniedbane i zaniechane obszary edukacji w szkole. Olsztyn, Wydawnictwo UWM.

Szatan E., 2016, Idea wykorzystania pracy zespołowej w doświadczaniu muzyki. Zajęcia muzyczno-ruchowe jako pole dla twórczości i kreatywności dzieci. W: E. Szatan, E.A. Muzioł, A. Komorowska-Zielony (red.), Emil Jaques-Dalcroze i jego idee w edukacji, sztuce i terapii. Gdańsk, Wydawnictwo UG.

Szatan E., Muzioł E.A., Komorowska-Zielony A. (red.), 2016, Emil Jaques-Dalcroze i jego idee w edukacji, sztuce i terapii. Gdańsk, Wydawnictwo UG.

Trzebiński J., 1978, Z badań nad uwarunkowaniami oryginalności myślenia. Wrocław, Wydawnictwo Ossolineum.

Uszyńska-Jarmoc J., 2003, Twórcza aktywność dziecka. Teoria - rzeczywistość perspektywy rozwoju. Białystok, Wydawnictwo Trans Humana.

Weiner A., 2000, Aktywność muzyczna w zintegrowanym systemie kształcenia wczesnoszkolnego. W: V. Przerembska (red.), Treści, formy i metody przedmiotu „muzyka” $w$ świetle reformy powszechnej edukacji: materiały z ogólnopolskiej konferencji naukowej (Łódź, 25-26 listopada 1999). Łódź, Wydawnictwo UŁ.

Weiner A., 2002, Przygotowanie absolwentów pedagogiki wczesnoszkolnej do realizacji edukacji muzycznej. W: L. Kataryńczuk-Mania, J. Karcz (red.), Wybrane zagadnienia edukacji artystycznej dzieci i młodzieży. Zielona Góra, Oficyna Wydawnicza UZ.

Wang Y., 2009, On Cognitive Foundations of Creativity and the Cognitive Process of Creation. "International Journal of Cognitive Informatics and Natural 
Intelligence", 3 (4), 1-18, pozyskano z: http://www.ucalgary.ca/icic/files/icic/63-IJCINI-3401-CogCreativity.pdf [dostęp: 15.04.2015].

Rozporządzenie Ministra Edukacji Narodowej z dnia 17 czerwca 2016 r. zmieniające rozporzadzenie w sprawie podstawy programowej wychowania przedszkolnego oraz kształcenia ogólnego w poszczególnych typach szkół, Dz. U., poz. 895, pozyskano z: http://dziennikustaw.gov.pl/du/2016/895 [dostęp: 07.03.2017]. Ministerstwo Edukacji Narodowej, 2014, Wspieranie rozwoju dziecka młodszego na pierwszym i kolejnych etapach edukacyjnych $w$ zwiąku $z$ obniżeniem wieku realizacji obowiązku szkolnego: materiaty adresowane do dyrektorów szkół i przedszkoli, kadry pedagogicznej, rodziców oraz organów prowadzacych szkoły podstawowe i przedszkola, pozyskano z: https://men.gov.pl/wp-content/uploads/2014/07/wspieranie_rozwoju_dziecka_mlodszego_1.pdf [dostęp: 17.04.2015].

\title{
THE CREATIONS AND CREATIVITY OF CHILDREN IN MUSIC AND MOVEMENT ACTIVITIES (FROM THE EXPERIENCE OF WORKING IN A SMALL CITY ENVIRONMENT)
}

\begin{abstract}
Modern life poses before people various challenges, many of which are associated with the need to be creative. And yet the sphere of amateur musical activity and education conducive to stimulating creativity in the education process of younger children is neglected. Creativity is often just an empty slogan in the core of the curriculum. The article describes a musical project implemented within the framework of extra-curricular activities, that was attended by children living in rural areas. It was based on the assumptions of Dalcroze Eurhythmics (also known as the Dalcroze Method) and one of the adopted strategies was to encourage the children's to be more self-reliant and to stimulate their creative behavior through musical activity. The completed project shows how one can develop a child by allowing it to be creative as well as what triggers the emotions within it. Experiencing music and situations associated with it, fosters the development of cognitive, emotional, aesthetic, or social spheres of children. In other words: both teachers and parents should consciously use strategies to encourage musical creativity of children and to develop their creativity. The teacher or instructor can use this to interpret music and movement, which are quite often neglected and undervalued.
\end{abstract}

Keywords: child, creativity, music, interpretations of music movement 